\title{
RISK ASSESSMENT IN ROAD TRANSPORT - STRATEGIC AND BUSINESS APPROACH
}

\section{OCENY RYZYKA W TRANSPORCIE DROGOWYM - PODEJŚCIE STRATEGICZNE I BIZNESOWE}

\begin{abstract}
Agnieszka Tubis
Wroclaw University of Science and Technology, Faculty of Mechanical Engineering Politechnika Wrocławska, Wydział Mechaniczny

Abstract: In the presented paper, author focus on the issues related to risk assessment of transport processes performance. The author presented the characteristics of the traditional approach to risk assessment in transport, which is popular in the literature. This approach addresses the strategic risk assessment for the road transport system and it focuses primarily on aspects related to the transport safety. The business approach to risk assessment from the perspective of the managers of the transport process is presented in the next part of the article. In this case, the subject of the analysis is the operational risk, which focuses on the risks affecting the implementation of the transport process and the achievement of the company's operational objective. The article concludes with a summary, including directions for further research.
\end{abstract}

Keywords: transportation process, risk assessment, safety

Streszczenie: $W$ artykule poruszono zagadnienie dotyczace oceny ryzyka wprocesie transportu drogowego. Autorka przedstawila charakterystyke tradycyjnego podejścia do oceny ryzyka $w$ transporcie, które dominuje w literaturze przedmiotu. Podejście to dotyczy strategicznej oceny ryzyka dla systemu transportu drogowego i koncentruje się przede wszystkim na aspektach zwiazanych z bezpieczeństwem przewozu. $W$ dalszej części artykułu przedstawiono biznesowe podejście do oceny ryzyka z perspektywy zarzadzajacych procesem transportowym. W tym przypadku przedmiotem analizy jest ryzyko operacyjne, które koncentruje sięna zagrożeniach wplywajacych na realizacje procesu przewozu $i$ osiagnięcie celu operacyjnego przedsiębiorstwa. Artykut kończy podsumowanie oraz wytyczne obejmujace kierunki dalszych badań.

Stowa kluczowe: proces transportowy, ocena ryzyka, bezpieczeństwo 
Risk assessment in road transport - strategic and business approach

Oceny ryzyka w transporcie drogowym - podejście strategiczne i biznesowe

\section{RISK ASSESSMENT IN ROAD TRANSPORT - STRATEGIC AND BUSINESS APPROACH}

\section{Introduction}

How risk is perceived depends largely on who assesses risk, what information they have, what algorithms of methods and models they recognise and what acceptance criteria they use. Key to risk management is clarity of terminology [32]. Aven has prepared detailed reviews of the definition of the concept of risk. He distinguished seven basic ways of understanding risk, which is the subject of scientific research. According to this classification, the risk can be understood as [5]:

- the possibility of an unfortunate occurrence,

- the potential for realisation of unwanted, negative consequences of an event,

- exposure to a proposition (e.g. the occurrence of a loss) of which one is uncertain,

- the consequences of the activity and associated uncertain- ties,

- uncertainty about and severity of the consequences of an activity with respect to something that humans value,

- the occurrences of some specified consequences of the activity and associated uncertainties,

- the deviation from a reference value and associated uncertainties.

The risk can be defined in different ways, as can be seen in the above definitions. Uncertainty is a concept that appears in most definitions. This is the element that accompanies the occurrence of the analyzed event and its consequences.

Risk assessment in road transport has been the subject of numerous research and scientific publications around the world for many years. This is one of the important research areas also in Poland. In 2007-2010, a scientific consortium led by the Gdansk University of Technology carried out the research project entitled "The integrated system of road safety - ZEUS"[39]. In the performed project work, the risk in road transport was defined as the uncertainties of taken by human activities[38]. The risk was also linked closely to the issue of choice understanding as taking a decision regarding the risk of dangerous behaviour with having a knowledge that there may happen an accident, or an attempts to limit, reduce or eliminate the risk of an accident occurrence by driving appropriate to the existing conditions. The authors of the project also found that the risk in road transport is a combination of the probability of hazard event activation and caused in connection with it the damages or losses[38]. In their research studies, the authors of the project emphasized clearly that in contrast to many fields of engineering, there had not been yet developed a uniform method of risk management for road transport. 
There are created only the basis for relevant methodology that is established on standard elements: risk analysis, valuation and risk assessment, and the removal of risk and control of remaining risk [38].

In the research project, the risk is analyzed in the context of safety. This approach is characteristic for technical sciences. It is also the main scope of research conducted all over the world in the field of road transport risk assessment. However, in the area of management methods, a business approach to risk assessment in road transport seems to be prevalent. In this case, the focus of researchers is centered on costs and logistics connected with completing the transportation process. This aspect of risk assessment research is by far less developed in the literature on the subject. Therefore, the aim of this article is to present two different approaches to risk assessment in road transport - a strategic one and a business one.

The first part of the article contains the results of researching academic publications connected with risk assessment in road transport which have appeared over the last 10 years and which focus mostly on the aspect of safety. The second part of the article discusses the business approach to risk assessment from the point of view of transport companies. The article ends with a summary and guidelines on directions for further research.

\section{Research methodology.}

The first stage of research procedure was defining the scope of risk analyses conducted for road transport which are described in international literature. To prepare a summary of the literature, the following academic journals databases have been used: ProQuest, Elsevier, ScienceDirect, Wiley Online Library. The records were searched according to the following key:

- the phrase "risk assessment" appearing in the title of the article and

- the phrase "road transport" appearing anywhere in the body of the article.

The search was limited to the years 2006-2017 in order to be able to concentrate only on the most recent research trends.

As a result, 363 articles that meet the assumed criteria have been selected and then further organized. From the selection, the following articles have been removed:

- copies of the same articles which appeared in different databases;

- articles in which the use of the phrase "road transport" was accidental (not connected with the subject);

- articles concerning pollution risk (soil pollution, concentrations of heavy metals etc.).

51 articles were accepted for further research. Articles came from a total of 31 magazines. 
Risk assessment in road transport - strategic and business approach Oceny ryzyka w transporcie drogowym - podejście strategiczne i biznesowe

A summary of the most important magazines is presented in Table 1:

Tab. 1 List of journals containing analyzed articles

\begin{tabular}{|c|l|c|}
\hline Lp. & \multicolumn{1}{|c|}{ Title of the journal } & $\begin{array}{c}\text { Number } \\
\text { of } \\
\text { articles }\end{array}$ \\
\hline 1. & Transportation Research & 6 \\
\hline 2. & Procedia - Social and Behavioral Sciences & 3 \\
\hline 3. & Process Safety and Environmental Protection & 3 \\
\hline 4. & Risk Analysis & 3 \\
\hline 5. & Safety Science & 3 \\
\hline 6. & Tunnelling and Underground Space Technology & 2 \\
\hline 7. & IEEE Transactions on Intelligent Transportation Systems & 2 \\
\hline 8. & Journal of Hazardous Materials & 2 \\
\hline 9. & Journal of Risk Research & 2 \\
\hline 10. & Procedia Engineering & 2 \\
\hline 11. & Risk Management & 2 \\
\hline 12. & Other & 20 \\
\hline
\end{tabular}

The number of articles published in subsequent years is shown in Figure 1.

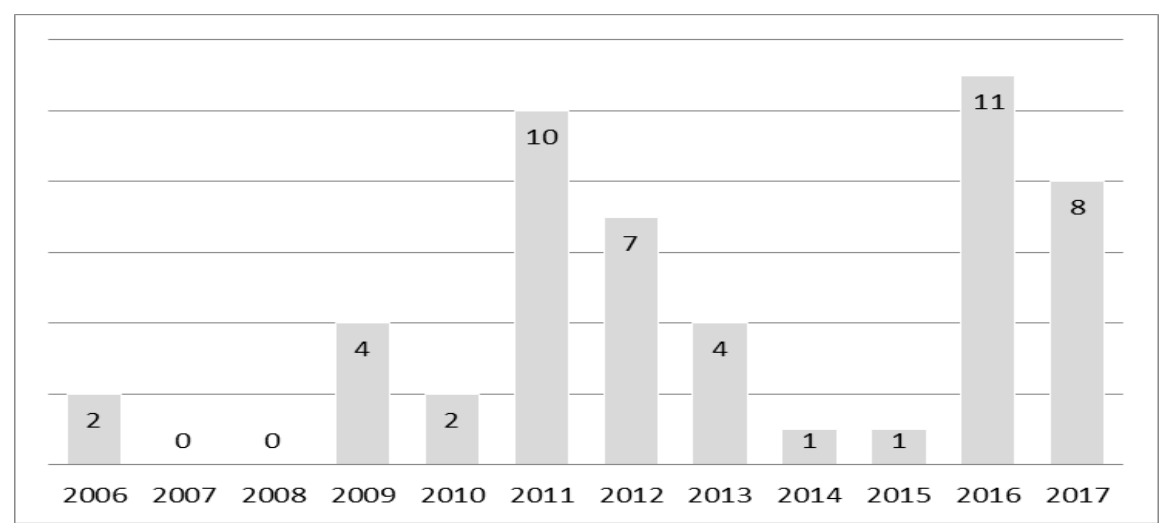

Fig. 1 Distribution of yearbooks of published articles

As we can see, most articles are from 2011-2012 and 2016-2017. It can therefore be concluded that the subject of risk assessment in transport is once again becoming important in the area of research.

\section{Strategic risk assessment in road transport}

The analysis of publications proves that risk assessment in road transport focuses for the most part on the macro scale, that is, it concerns mostly strategic risk assessment. Strategic risk is a long-term risk connected with long-term decisions taken by institutions controlling road safety in the analysed area. It is connected with uncertainty about completing the strategic goal of protecting life and health of all the traffic participants [31]. Therefore, strategic risk is mostly assessed in the context of safety issues. 
The analysis of articles that have appeared in the last 10 years in various academic journals seems to prove this point. The hazards that are assessed can be assigned to one of 9 groups:

- traffic accident (RA1)

- terrorist attack (RA2)

- infrastructure (RA3)

- threat to human health (RA4)

- environmental hazards (RA5)

- incorrect driver behavior (RA6)

- operation costs (RA7)

- negative natural phenomena (RA8)

- other (RA9).

The most research publications concentrate on assessing risk connected with road accidents and with the reliability of the transport infrastructure being used. The detailed summary of the number of articles and their assignment to specific groups is shown in Table 2.

Tab. 2 Assignment of articles to selected thematic groups

\begin{tabular}{|c|c|c|l|}
\hline Lp. & $\begin{array}{c}\text { Group } \\
\text { symbol }\end{array}$ & $\begin{array}{c}\text { Number of } \\
\text { articles }\end{array}$ & \multicolumn{1}{|c|}{ Assigned articles } \\
\hline 1. & RA1 & 20 & $\begin{array}{l}{[1],[2],[8],[10],[11],[12],[13],[14],} \\
{[15],[16],[18],[27],[34],[35],[37],} \\
{[41],[43],[45],[47],[60]}\end{array}$ \\
\hline 2. & RA2 & 2 & {$[3],[6]$} \\
\hline & & & $\begin{array}{l}{[3],[7],[8],[11],[12],[17],[21],[24],} \\
{[28],[29],[33],[36],[42],[43],[46],} \\
{[48],[49],[50],[53],[55]}\end{array}$ \\
\hline 3. & RA3 & 21 & {$[23],[26],[55]$} \\
\hline 4. & RA4 & 3 & {$[9],[13],[14],[15],[16],[26]$} \\
\hline 5. & RA5 & 6 & {$[44]$} \\
\hline 6. & RA6 & 1 & {$[11],[52],[56]$} \\
\hline 7. & RA7 & 3 & {$[17],[22]$} \\
\hline 8. & RA8 & 2 & {$[4],[19],[20],[22],[25],[40],[57]$} \\
\hline 9. & RA9 & 7 &
\end{tabular}

In the concept of risk management the risk is described as an occurrence which, if it happens, affects the goals set by the organisation [58]. When analysing the transport process, there are three criteria for assessing whether the goals have been achieved:

- safety aspect;

- the aspect of staying within the budget;

- the aspect of meeting the declared logistic parameters. 
Risk assessment in road transport - strategic and business approach Oceny ryzyka w transporcie drogowym - podejście strategiczne i biznesowe

The next step of the research project was therefore classifying the results as one of the three criteria assessing the compliance of the transportation process. The results of the classification are shown as percentage share in fig.2.

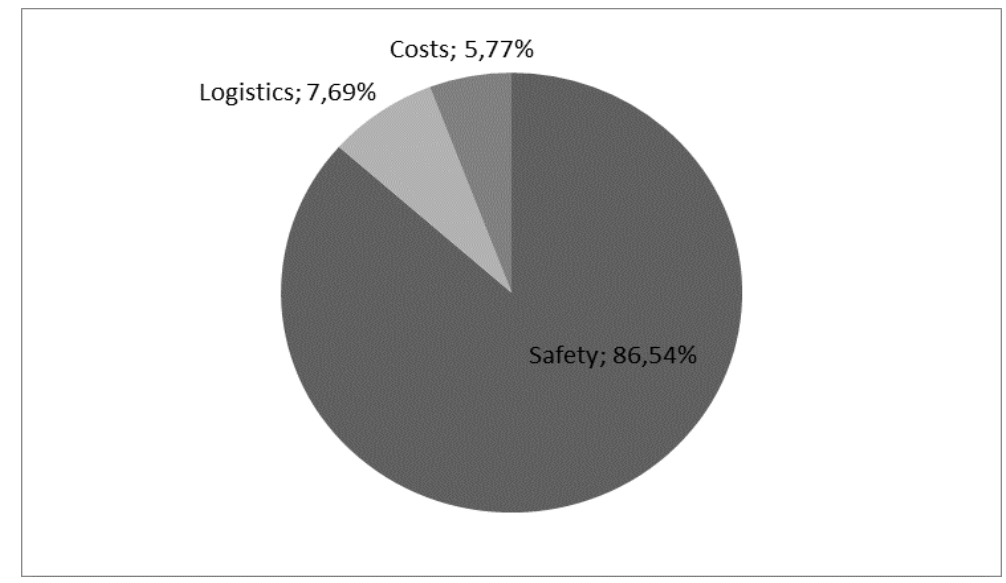

Fig. 2 Assignment of results to the criteria for assessing the compliance of the transport process

A detailed analysis of the content of the research presented in the articles proves that the most publications on risk assessment in road transport concentrate mostly on the safety aspect of the transportation process.

\section{Risk assessment from the point of view of the transport company}

However, long-term risk is also the subject of analysis for transport companies. In this case, the scope of analysis concerns strategic, technological, social, legal and environmental aspects. [54]. These aspects determine development trends for the economy and the region, and the risk connected with them on company level. They comprise the risk of wrongly assessing trends in company development, forecasting risk and the risk of not achieving strategic goals of the company [54]. However, when approaching issues connected with safety of road transport, freight companies often apply a stochastic theory. According to it, the occurrence of road accidents is purely random and people have no control over it. [30]. Therefore, in this case the most popular risk management method for transport companies is purchasing insurance. As a result, transport companies are not interested in analysing risk connected with road accidents, as long as they are not too commonplace and do not affect the drivers repeatedly.

The risk assessment that road companies are interested in concerns mostly the hazards affecting proper completion of transporting cargo from point A to point B. 
As Wilson states [59], it is the disruptions in transport happening between the supplier and distributor / warehouse that affect the efficiency of supply chain the most.

Therefore, transport managers when assessing risk often tend to think short-term, which means that their analyses focus on operational risk assessment. This risk is assessed as the risk of insufficient efficiency of operations in achieving current goals. It comprises the possibility of not having the right qualifications, not meeting technical or efficiency requirements or of willful misconduct [61].

Therefore, what needs to be assessed is the efficiency of internal processes of the companies and their resistance to disturbances, so that the goals can be achieved. The focus of the managers responsible for risk assessment connected with transporting cargo is concentrated on meeting the requirements concerning [51]:

- the assumed logistic parameters for the delivery (delivery on time and complete);

- conditions of transport (meeting the requirements concerning safety - driving time, average speed on route, securing the cargo);

- the conditions of the transport fleet;

- proper documentation management;

- quality of service.

The point of reference here is the assessment of complete logistic service provided by the transport company, comprising the stage of organizing the transport as well as the transport itself. The assessed risk concerns uncertainty of completing business aims assumed for the transport process, namely, completing transport service in accordance with budget, quality and logistic requirements.

\section{Summary}

Review of the articles on risk assessment for road transport proves that the issue is researched widely all over the world. The main focus of researchers is on the safety aspect of risk assessment, particularly on the causes and effects of accidents on roads and on reliability of transport infrastructure. On the other hand, there's a demand appearing on the market for models of risk assessment adapted to the decisive needs of transport companies. The managers responsible for organizing transport focus mostly on company's business goals when assessing the risk. They treat road accidents and hazards resulting from incorrectly prepared infrastructure as external factors out of their control. Their focus is mostly on internal processes of the company and possibility of improving them after conducting operational risk assessment. Therefore, it is necessary to prepare a multi-criteria method of risk assessment for road transport, one that would meet the needs of managerial staff in transport companies. 
Risk assessment in road transport - strategic and business approach Oceny ryzyka w transporcie drogowym - podejście strategiczne i biznesowe

The research presented in this article is part of "Identifying data supporting risk assessment in road transport system in the aspect of safety and meeting logistic standards" program financed as part of MINIATURA 1 program. The next stages of research will be directed to the identification of information collected by transport companies for the purpose of risk analysis and assessment in their operations.

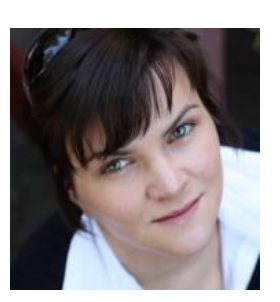

Ph.D. Agnieszka Tubis, Wroclaw University of Science and Technology, Faculty of Mechanical Engineering, Department of Maintenance and Operation of Logistic, Transportation and Hydraulic Systems. PhD Dissertation concerned the cooperation of manufacturers and retailers in the area of planning, forecasting and replenishment according to the concept of CPFR. Current interests are connected with the concept of risk management in transport companies, process controlling being implemented in the maintenance and operations management of vehicles, and she is interests in systems that support decision-making processes of managers in the road transport companies. 


\section{OCENY RYZYKA W TRANSPORCIE DROGOWYM - PODEJŚCIE STRATEGICZNE I BIZNESOWE}

\section{Wstęp}

To, jak postrzegane jest ryzyko, zależy w dużej mierze od tego, kto ocenia ryzyko, jakie ma informacje, jakie algorytmy metod i modeli rozpoznaje oraz jakie kryteria akceptacji stosuje [32]. Szczegółowego przeglądy definicji pojęcia ryzyko dokonał Aven. Wyróżnił on 7 dominujących sposobów pojmowania ryzyka, które jest przedmiotem prowadzonych badań naukowych. Zgodnie z tą klasyfikacją ryzyko może być pojmowane jako [5]:

1) Możliwość wystąpienia negatywnego zdarzenia.

2) Możliwość wystąpienia / osiągnięcia niepożądanych skutków zdarzenia.

3) Narażenie na wynik (np. stratę), którego wystąpienie jest niepewne.

4) Konsekwencja działalności i związane z nią niepewne powiązania.

5) Niepewność co do dotkliwości skutków działalności w odniesieniu do elementów stanowiących wartość dla ludzi.

6) Wystąpienie określonych konsekwencji działalności i związanych $\mathrm{z}$ nią niepewności.

7) Odchylenia od rekomendowanej wartości i związanych z tym niepewności.

Jak widać z powyższych definicji, ryzyko może być definiowane w różnych sposób. To co jest charakterystyczne i powtarza się w większości przytoczonych definicji to niepewność towarzyszącą wystąpieniu danego zjawiska oraz jego konsekwencje / skutki. Identyfikacja zbioru zdarzeń zależy jednak w dużej mierze od celu, jaki stawiany jest analizowanemu procesowi. Kryterium celu definiuje bowiem zakres przeprowadzanej oceny ryzyka.

Ocena ryzyka $w$ transporcie drogowym od wielu lat jest przedmiotem licznych badań i publikacji naukowych na całym świecie. Również w Polsce jest to jeden $\mathrm{z}$ istotnych obszarów badawczych. Na szczególną uwagę zasługuje projekt pt. „Zintegrowany system bezpieczeństwa drogowego - ZEUS” realizowany w latach 2007-2010 przez konsorcjum naukowe kierowane przez Politechnikę Gdańską [39]. W ramach prowadzonych badań uczestnicy projektu, zdefiniowali ryzyko w ruchu drogowym jako niepewność rezultatu podejmowanych przez człowieka działań [38]. Ryzyko powiązano również ściśle z kwestią wyboru, czyli decyzją dotyczącą podjęcia ryzyka niebezpiecznych zachowań, przy posiadanej wiedzy, że może dojść do wypadku, albo dotyczącą próby ograniczenia, redukcji lub eliminacji ryzyka wypadku poprzez jazdę adekwatną do istniejących warunków. Autorzy projektu stwierdzili również, iż ryzyko w transporcie drogowym jest kombinacją prawdopodobieństwa aktywizacji zagrożenia w zdarzeniu niepożądanym i spowodowanych w związku z tym szkód. [38]. 
Risk assessment in road transport - strategic and business approach Oceny ryzyka w transporcie drogowym - podejście strategiczne i biznesowe

W swoich opracowaniach, autorzy projektu podkreślają wyraźnie, iż w przeciwieństwie do wielu dziedzin techniki, w transporcie drogowym nie wypracowano do tej pory jednolitej metody zarządzania ryzykiem. Tworzone są dopiero podstawy odpowiedniej metodyki bazującej na standardowych elementach: analizie ryzyka, wartościowaniu i ocenie ryzyka oraz na usuwaniu ryzyka i sterowaniu ryzykiem pozostałym. [38]

Omawiany projekt badawczy analizuje ryzyko w kontekście bezpieczeństwa. Podejście to jest charakterystyczne dla nauk technicznych. Jest to również główny nurt badań prowadzonych na świecie $\mathrm{w}$ tematyce poświęconej ryzyku w transporcie drogowym. W obszarze metod zarządzania dominujące jest natomiast podejście biznesowe do oceny ryzyka w transporcie drogowym. Uwaga badaczy jest wówczas skoncentrowana na wynikach logistycznych i kosztowych związanych $\mathrm{z}$ realizacją procesu przewozu drogowego. Ten obszar badań nad analizą ryzyka jest zdecydowanie mniej rozwinięty w literaturze przedmiotu. $\mathrm{Z}$ tego też względu celem artykułu jest prezentacja dwóch różnych podejść do oceny ryzyka w transporcie drogowym - podejścia strategicznego i biznesowego. W pierwszej części artykułu przedstawiono wyniki badań publikacji naukowych, które ukazały się w ostatnich 10 latach i związane są z oceną ryzyka w transporcie drogowym. Tematyka tych artykułów koncentruje się przede wszystkim na aspektach bezpieczeństwa. W drugiej części artykułu rozpatrzono biznesowe podejście do oceny ryzyka $\mathrm{z}$ punktu widzenia przedsiębiorstw transportowych. Artykuł kończy podsumowanie oraz wytyczne obejmujące kierunki dalszych badań.

\section{Metoda prowadzonych badań.}

Pierwszym etapem postępowania badawczego było określenie zakresu przeprowadzanych analiz ryzyka dla transport drogowego, opisywanych w literaturze światowej. Do przygotowania przeglądu literaturowego wykorzystano następujące bazy czasopism: ProQuest, Elsevier, ScienceDirect, Wiley Online Library. Rekordy wykorzystywanych baz przeszukiwane były według następującego klucza:

- hasło „risk assessment” pojawiające się w tytule artykułu oraz

- hasło „road transport” pojawiające się w dowolnym fragmencie artykułu.

Zakres wyszukiwania ograniczono do lat 2006 - 2017, tak aby móc skupić uwagę na najnowszych trendach badawczych.

W procesie wyszukiwania uzyskano dostęp do 363 artykułów spełniających wymogi przyjętego klucza. Artykuły te zostały poddane dalszemu procesowi uporządkowania. $Z$ otrzymanego zbioru artykułów wyeliminowano:

- powtórzenia tego samego artykułu, który pojawiał się w różnych bazach czasopism;

- artykuły, w których użycie pojęcia „road transport” było przypadkowe (nie związane z tematem);

- artykuły dotyczące ryzyka skażenia z powodu spalin (skażenie gleby, stężenie metali ciężkich itp.). 
Ostatecznie do dalszych badań przyjęto 50 artykułów, pochodzących łącznie z 31 czasopism recenzowanych. Zestawienie najważniejszych czasopism przedstawiono w tabeli 1:

Tab. 1 Czasopisma stanowiace podstawe przeprowadzanego przegladu literaturowego

\begin{tabular}{|c|l|c|}
\hline Lp. & \multicolumn{1}{|c|}{ Tytuł czasopisma } & $\begin{array}{c}\text { Liczba } \\
\text { artykułów }\end{array}$ \\
\hline 1. & Transportation Research & 6 \\
\hline 2. & Procedia - Social and Behavioral Sciences & 3 \\
\hline 3. & Process Safety and Environmental Protection & 3 \\
\hline 4. & Risk Analysis & 3 \\
\hline 5. & Tunnelling and Underground Space Technology & 3 \\
\hline 6. & Safety Science & 2 \\
\hline 7. & IEEE Transactions on Intelligent Transportation Systems & 2 \\
\hline 8. & Journal of Hazardous Materials & 2 \\
\hline 9. & Journal of Risk Research & 2 \\
\hline 10. & Procedia Engineering & 2 \\
\hline 11. & Risk Management & 2 \\
\hline 12. & Inne & 20 \\
\hline
\end{tabular}

Ilość artykułów przypadających na poszczególne lata publikacji przedstawiono na rysunku 1.

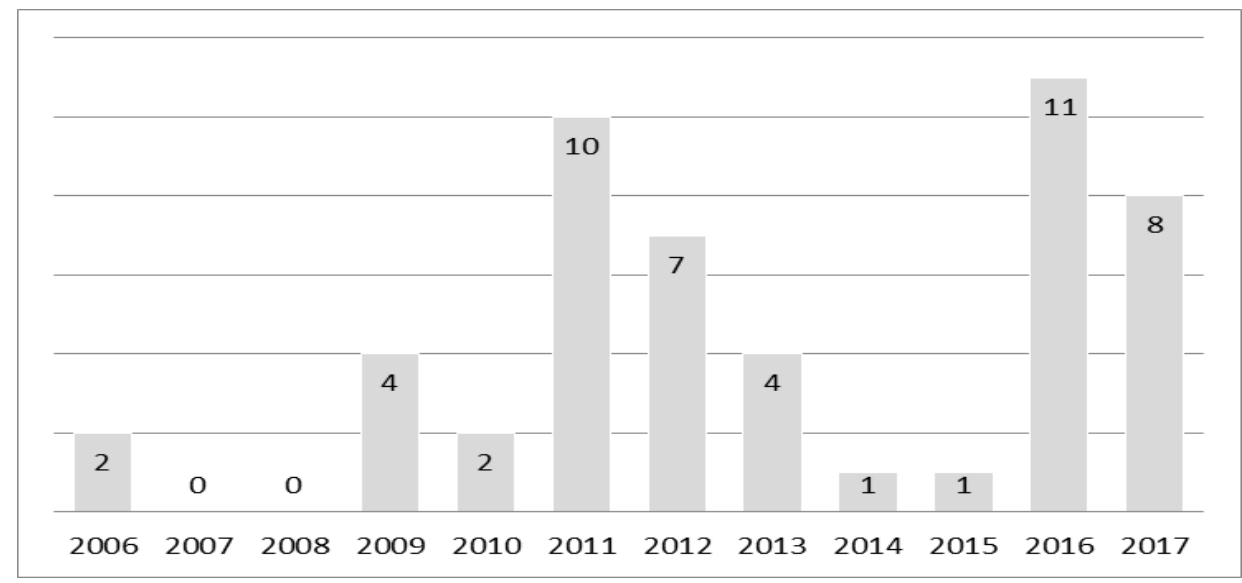

Rys. 1 Rozkład roczników publikowanych artykułów

Jak widać na przedstawionym wykresie większość artykułów pochodzi z lat 20112012 oraz 2016-2017. Można więc stwierdzić, iż tematyka związana z oceną ryzyka $\mathrm{w}$ transporcie nabiera znowu istotnego znaczenia $\mathrm{w}$ obszarze prowadzonych badań. 
Risk assessment in road transport - strategic and business approach Oceny ryzyka w transporcie drogowym - podejście strategiczne i biznesowe

\section{Ocena ryzyka strategicznego $w$ transporcie drogowym}

Przeprowadzona analiza publikacji dowodzi, iż ocena ryzyka w transporcie drogowym najcześciej koncentruje się na skali makro, a więc dotyczy przede wszystkim oceny ryzyka strategicznego. Ryzyko strategiczne jest ryzykiem długookresowym, związanym $\mathrm{z}$ decyzjami długofalowymi, podejmowanymi przez instytucje zarządzające bezpieczeństwem ruchu drogowego na analizowanym obszarze. Ryzyko strategiczne związane jest z niepewnością dotycząca realizacji celu strategicznego, jakim jest ochrona życia i zdrowia uczestników ruchu drogowego [31]. $Z$ tego też względu ryzyko strategiczne oceniane jest przede wszystkim przez pryzmat zagadnień związanych z bezpieczeństwem.

Potwierdza to analiza artykułów pojawiających się $\mathrm{w}$ ostatnich 10 latach w czasopismach naukowych poświęconych tej tematyce. Zagrożenia będące przedmiotem dokonywanej oceny można przypisać do jednej z 9 wyróżnionych grup:

- wypadek drogowy (RA1)

- atak terrorystyczny (RA2)

- infrastruktura (RA3)

- zagrożenie dla zdrowia ludzi (RA4)

- zagrożenia dla środowiska (RA5)

- nieprawidłowe zachowania kierowców (RA6)

- koszty realizacji (RA7)

- negatywne zjawiska naturalne (RA8)

- inne (RA9).

Najwięcej publikowanych badań koncentruje się na ocenie ryzyka związanego $\mathrm{z}$ wypadkami drogowymi oraz $\mathrm{z}$ niezawodnością wykorzystywanej infrastruktury transportowej. Niektórzy autorzy $w$ swoich badaniach zajmują się oceną ryzyka, dotyczącego więcej niż jednego z wyróżnionych zagadnień. Szczegółowe zestawienie liczby artykułów wraz z ich przypisaniem do wyróżnionych grup przedstawiono w tabeli 2.

Tab. 2 Przypisanie artykułów do wyróżnionych grup tematycznych

\begin{tabular}{|c|c|c|l|}
\hline Lp. & $\begin{array}{c}\text { Symbol } \\
\text { grupy }\end{array}$ & $\begin{array}{c}\text { Liczba } \\
\text { artykułów }\end{array}$ & \multicolumn{1}{|c|}{ Przypisane artykuły } \\
\hline 1. & RA1 & 20 & $\begin{array}{l}{[1],[2],[8],[10],[11],[12],[13],[14],} \\
{[15],[16],[18],[27],[34],[35],[37],} \\
{[41],[43],[45],[47],[60]}\end{array}$ \\
\hline 2. & RA2 & 2 & {$[3],[6]$} \\
\hline 3. & RA3 & 21 & $\begin{array}{l}{[3],[7],[8],[11],[12],[17],[21],[24],} \\
{[28],[29],[33],[36],[42],[43],[46],} \\
{[48],[49],[50],[53],[55]}\end{array}$ \\
\hline 4. & RA4 & 3 & {$[23],[26],[55]$} \\
\hline 5. & RA5 & 6 & {$[9],[13],[14],[15],[16],[26]$} \\
\hline 6. & RA6 & 1 & {$[44]$} \\
\hline 7. & RA7 & 3 & {$[11],[52],[56]$} \\
\hline 8. & RA8 & 2 & {$[17],[22]$} \\
\hline 9. & RA9 & 7 & {$[4],[19],[20],[22],[25],[40],[57]$} \\
\hline
\end{tabular}


W koncepcji zarządzania ryzykiem, ryzyko ujmuje się w kategoriach zdarzenia, które jeśli się wydarzy, negatywnie wpłynie na osiągane przez organizację cele [58]. Analizując przebieg procesu transportu weryfikuje się osiągnięcie celu przez pryzmat trzech kryterów oceniających:

- kryterium bezpieczeństwa;

- kryterium dotrzymania zakładanych kosztów;

- kryterium dotrzymania deklarowanych parametrów logistycznych.

Kolejnym etapem prac badawczych było $\mathrm{w}$ związku $\mathrm{z}$ tym zakwalifikowanie opisywanych wyników do jednego z trzech kryteriów oceniających poprawność realizowanego przewozu. Wyniki przeprowadzonej klasyfikacji przedstawiono w formie udziałów procentowych na rysunku 2.

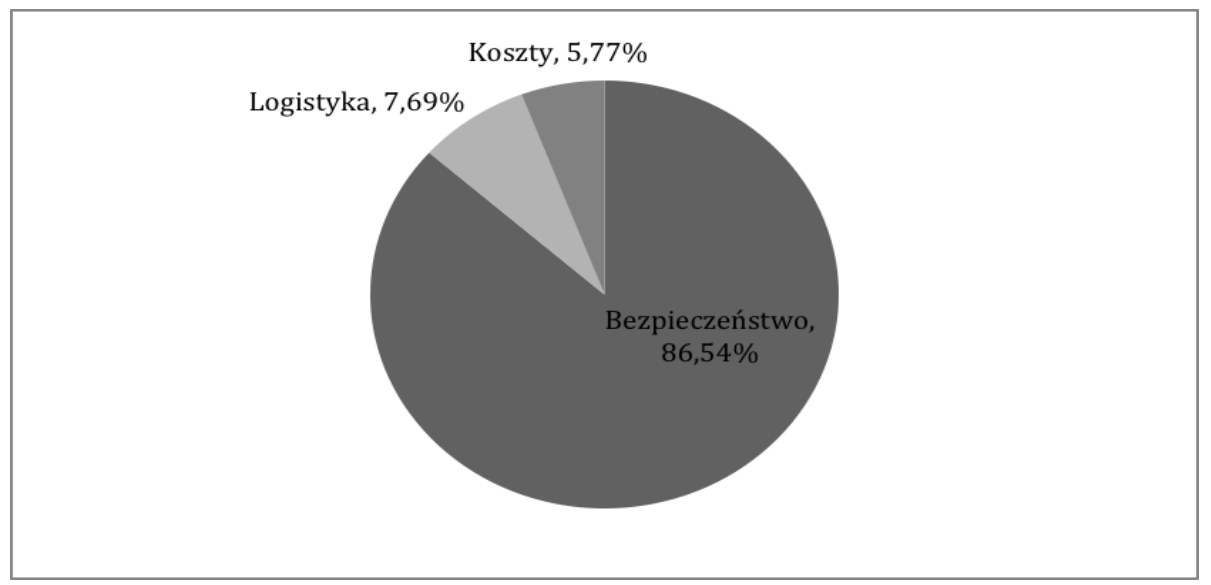

Rys. 2 Przypisanie opisywanych badań do kryteriów oceniajacych poprawność procesu transportu

Szczegółowa analiza zawartości merytorycznej przedstawionych w artykułach badań dowodzi słuszności spostrzeżenia, iż większość publikacji poświęconych zagadnieniom oceny ryzyka $\mathrm{w}$ transporcie drogowym koncentruje się przede wszystkim na aspektach związanych $\mathrm{z}$ bezpieczeństwem realizowanych przewozów.

\section{Ocena ryzyka z punktu widzenia przedsiębiorstwa transportowego}

Długoterminowe ryzyko jest również przedmiotem analizy przedsiębiorstw transportowych. Obszar analizy w tym przypadku dotyczy czynników strategicznych, technologicznych, społecznych, prawnych i środowiskowych [54]. Czynniki te determinują trendy rozwojowe gospodarki i regionu oraz związane z nimi ryzyko na poziomie przedsiębiorstwa. Należą do nich ryzyko błędnej oceny trendów w rozwoju przedsiębiorstwa, ryzyko prognozy oraz ryzyko nieosiągnięcia strategicznych celów przedsiębiorstwa [54]. 
Risk assessment in road transport - strategic and business approach Oceny ryzyka w transporcie drogowym - podejście strategiczne i biznesowe

Jednakże do zagadnień związanych $\mathrm{z}$ bezpieczeństwem ruchu drogowego, przedsiębiorstwa przewozowe bardzo często podchodzą zgodnie $\mathrm{z}$ teorią stochastyczną. Zgodnie z nią zjawisko wypadków drogowych ma charakter czysto losowy, a człowiek nie ma nad nimi żadnej kontroli [30]. Z tego względu najbardziej popularnym sposobem zarządzania ryzykiem $\mathrm{z}$ tym związanym jest wykup przez przewoźników pakietu ubezpieczeń. Przewoźnik nie jest więc zainteresowany analizą ryzyka związanego $\mathrm{z}$ charakterystyką rejestrowanych wypadków drogowych, jeżeli tylko nie ma miejsca nagminne uczestnictwo wybranych kierowców w takich zdarzeniach.

Ocena ryzyka, będąca przedmiotem zainteresowania przedsiębiorstw transportu drogowego, koncentruje się jednak przede wszystkim na zagrożeniach zakłócających poprawność realizacji procesu przewozu ładunku z punktu A do punktu B. Jak stwierdził bowiem Wilson [59] to właśnie zakłócenia w transporcie, które występują między dostawcą a magazynem / dystrybutorem, mają największy wpływ na wydajność łańcucha dostaw. $Z$ tego względu zarządzający transportem oceniając ryzyko, przyjmują zazwyczaj perspektywę bliskiego horyzontu czasowego, a w związku z tym ich analizy ukierunkowane są na ocenę ryzyka operacyjnego. Ryzyko to jest rozważane jako ryzyko niedostatecznej skuteczności działania z perspektywy celu operacyjnego (bieżącego) tego działania. Polega ono więc na możliwości niespełnienia oczekiwań technicznych, efektywności lub kwalifikacji, a także umyślnego popełnienia szkody [61]. Ocenie podlega w związku z tym skuteczność procesów wewnętrznych przedsiębiorstwa oraz ich odporność na zakłócenia, tak by organizacja mogła realizować swoje cele.

W związku z powyższym uwaga menedżerów, odpowiedzialnych za ocenę ryzyka towarzyszącego przewozom towarowym w transporcie drogowym, skoncentrowana jest na spełnieniu wymagań dotyczących[51]:

- przyjętych parametrów logistycznych dla dostawy (terminowość, kompletność);

- warunków przewozu (spełnienie wymogów dotyczących bezpieczeństwa przewozu - czas jazdy, średnia prędkość na trasie, zabezpieczenia towaru);

- warunków wykorzystywanej floty transportowej;

- poprawności zarządzania dokumentacją;

- jakości usługi.

Punktem odniesienia w tym przypadku jest ocena realizacji obsługi logistycznej świadczonej przez przewoźnika, obejmująca etap organizacji transportu i samego przewozu. Oceniane ryzyko dotyczy niepewności realizacji celu biznesowego założonego dla procesu transportu, a mianowicie wykonania usługi przewozowej zgodnie z przyjętymi warunkami logistycznymi, jakościowymi oraz kosztowymi.

\section{Podsumowanie}

Przegląd artykułów poświęconych tematyce oceny ryzyka w transporcie drogowym dowodzi, iż zagadnienie to jest aktualnie przedmiotem wielu badań prowadzonych na świecie. Główna uwaga badaczy skoncentrowana jest przede wszystkim na analizie ryzyka przeprowadzanej pod kątem bezpieczeństwa na drogach. 
W szczególności koncentrują się oni na przyczynach i konsekwencjach wypadków drogowych oraz na niezawodności infrastruktury transportowej.

$\mathrm{Z}$ drugiej strony pojawia się zapotrzebowanie na modele analizy ryzyka dostosowane do potrzeb decyzyjnych przedsiębiorstw transportowych. Menedżerowie odpowiedzialni za organizację przewozu, w swojej ocenie ryzyka kierują się przede wszystkim celami biznesowymi przedsiębiorstwa. Zjawisko wypadków drogowych i zagrożenia wynikające z nieprawidłowo przygotowanej infrastruktury traktują jako czynniki zewnętrzne, będące poza ich kontrolą. Ich uwaga skoncentrowana jest przede wszystkim na procesach wewnętrznych przedsiębiorstwa i możliwości ich doskonalenia na podstawie przeprowadzonej oceny ryzyka operacyjnego. $\mathrm{Z}$ tego też względu konieczne jest opracowanie wielokryterialnej metody oceny ryzyka dla procesu transportu drogowego, która odpowiadać będzie potrzebom decyzyjnym kadry menedżerskiej w przedsiębiorstwach transportowych.

Badania przedstawione $\mathrm{w}$ niniejszym artykule są pierwszym etapem projektu „Identyfikacja zbiorów informacji zasilających system oceny ryzyka w transporcie drogowym w aspekcie bezpieczeństwa i spełnienia standardów logistycznych" finansowanych $\mathrm{w}$ ramach programu MINIATURA 1. Kolejne etapy ukierunkowane zostaną na identyfikację informacji gromadzonych przez przedsiębiorstwa transportowe na potrzeby analizy i oceny ryzyka w prowadzonej działalności.

\section{Literatura}

[1] Agarwal P.K., Patil P.K., Mehar R.: A Methodology for Ranking Road Safety Hazardous Locations Using Analytical Hierarchy Process. Procedia - Social and Behavioral Sciences , 2013, 104, 1030 - 1037

[2] Ambituuni A., Amezaga J.M., Werner D.: Risk assessment of petroleum product transportation by road: A framework for regulatory improvement. Safety Science, 2015, 79, 324-335

[3] Ambros J., Havránek P., Valentová V., Krivankova Z., Striegler R.: Identification of hazardous locations in regional road network - comparison of reactive and proactive approache., Transportation Research Procedia, 2016, $14,4209-4217$

[4] Augutis J., Krikstolaitis R., Urbonas R., Uspuras E.: Hazard distribution and risk assessment in the network systems, Stochastic Environmental Research and Risk Assessment, 2006, 21, 51-61

[5] Aven T.: Risk assessment and risk management: review of recent advances on their foundation. European Journal of Operational Research, 2016, 253, 1-13

[6] Bajpai S., Sachdeva A., Gupta J.P.: Security risk assessment: Applying the concepts of fuzzy logic. Journal of Hazardous Materials, 2010, 173, 258-264 
Risk assessment in road transport - strategic and business approach Oceny ryzyka w transporcie drogowym - podejście strategiczne i biznesowe

[7] Beard A.N.: Tunnel safety, risk assessment and decision-making. Tunnelling and Underground Space Technology, 2010, 25, 91-94

[8] Benekos I., Diamantidis D.: On risk assessment and risk acceptance of dangerous goods transportation through road tunnels in Greece. Safety Science, 2017, 91, 1-10

[9] Bourliva A., Christophoridis Ch., Papadopoulou L., Giouri K., Papadopoulos A., Mitsika E., Fytianos K.: Characterization, heavy metal content and health risk assessment of urban road dusts from the historic center of the city of Thessaloniki, Greece. Environ Geochem Health, 2017, 39, 611-634

[10]Cai X., Wang C., Chen S., Lu J.: Model Development for Risk Assessment of Driving on Freeway under Rainy Weather Conditions. PLoS ONE, 2016, 11(2)

[11] Caliendo C., De Guglielmo M.L.: Accident Rates in Road Tunnels and Social Cost Evaluation. Procedia - Social and Behavioral Sciences, 2012, 53, 166 - 177

[12] Caliendo C., De Guglielmo M.L.: Quantitative Risk Analysis on the Transport of Dangerous Goods Through a Bi-Directional Road Tunnel. Risk Analysis, 2017, 37(1)

[13] Chakrabarti U.K., Parikh J.K.: Applying HAZAN methodology to hazmat transportation risk assessment. Process Safety and Environmental Protection, 2012, 90, 368-375

[14]Chakrabarti U.K., Parikh J.K.: Route evaluation for hazmat transportation based on total risk - A case of Indian State Highways. Journal of Loss Prevention in the Process Industries, 2011, 24, 524-530

[15] Chakrabarti U.K., Parikh J.K.: Route risk evaluation on class-2 hazmat transportation. Process Safety and Environmental Protection, 2011, 89, 248-260

[16] Chakrabarti U.K., Parikh J.K.: A societal risk study for transportation of class3 hazmats - A case of Indian state highways. Process Safety and Environmental Protection, 2013, 91, 275-284

[17]Clarke J., Obrien E.: A multi-hazard risk assessment methodology, stress test framework and decision support tool for transport infrastructure networks. Transportation Research Procedia, 2016, 14, 1355 - 1363

[18] Conca A., Ridella Ch., Sapori E.: A risk assessment for road transportation of dangerous goods: a routing solution. Transportation Research Procedia, 2016, $14,2890-2899$

[19] Costa L.N., Sapino M., Pippione S., Mattalia G., Saracco M., Di Trani S., Zanasi C.: Risk assessment in stock calf transportation from France to Italy: the contribution of road inspections. Italian Journal of Animal Science, 2012, $11-16$ 
[20]Dadsena K.K., Naikan V. N.A. Sarmah S.P.: A Methodology for Risk Assessment and Formulation of Mitigation Strategies for Trucking Industry. International Journal of Performability Engineering, 2016, 12(6), 573-588

[21]Decò A., Frangopol D.M.: Risk assessment of highway bridges under multiple hazards. Journal of Risk Research, 2011, 14(9), 1057 -1089

[22] Douglas J., Serrano J.-J., Coraboeuf D., Bouc O., Arnal C., Robida F., Modaressi H., Atkinson M., Vowles G., Holt I.: Risk assessment for the road network in the French-Italian border region using web services. First European Conference on Earthquake Engineering and Seismology (a joint event of the 13th ECEE \& 30th General Assembly of the ESC), 2006, 827

[23] Du Y., Gao B., Zhou H., Ju X., Hao H., Yin S.: Health risk assessment of heavy metals in road dusts in urban parks of Beijing, China. Procedia Environmental Sciences, 2013, 18, 299 - 309

[24] Duchaczek A., Skorupka D.: Risk assessment as a safety element in temporary bridge exploitation. European Journal of Environmental and Civil Engineering, 2016, 21(10), 1253-1269

[25]East A., Smale N., Kang S.: A method for quantitative risk assessment of temperature control in insulated boxes. International Journal of Refrigeration, 2009, 32, 1505-1513

[26]Faiz Y., Siddique N., Tufail M.: Pollution level and health risk assessment of road dust from an expressway. Journal of Environmental Science and Health, Part A, 2012, 47(6), 818-829

[27] Ghazel M.: Using Stochastic Petri Nets for Level-Crossing Collision Risk Assessment. IEEE Transactions On Intelligent Transportation Systems, 2009, $10(4)$

[28]Holicky M.: Probabilistic risk optimization of road tunnels. Structural Safety, 2009, 31, 260-266

[29] Hong E-S., Lee I-M., Shin H-S., Namc S-W., Kong J-S.: Quantitative risk evaluation based on event tree analysis technique: Application to the design of shield TBM. Tunnelling and Underground Space Technology, 2009, 24, 269-277

[30] Jamroz K.: Review of Road Safety Theories and Models. Journal of KONBiN, 2008, 1(4), 89-108

[31] Jamroz K.: Miary ryzyka strategicznego w ruchu drogowym. Journal of KONBiN, 2010, 1(13), $197-208$

[32] Jamroz K., Kadziński , Chruzik K., Szymanek A., Gucma L., Skorupski J. : TRANS-RISK - zintegrowana metoda zarządzania ryzykiem $\mathrm{w}$ transporcie. Journal of KONBiN, 2010, 1(13), 209-220

[33] Jančaříková E., Mikolaj J., Danišovič P.: Risk and incidents assessment in Slovak road tunnels. Procedia Engineering, 2017, 192, 376 - 380 
Risk assessment in road transport - strategic and business approach Oceny ryzyka w transporcie drogowym - podejście strategiczne i biznesowe

[34]Jurewicz Ch., Excel R.: Application of a crash-predictive risk assessment model to prioritise road safety investment in Australia. Transportation Research Procedia, 2016, 14, 2101 - 2110

[35] Kaundinya I., Nisancioglu S., Kammerer H., Oliva R.: All-hazard guide for transport infrastructure. Transportation Research Procedia, 2016, 14, 1325 1334

[36] Kazaras K., Kirytopoulos K.: Challenges for current quantitative risk assessment (QRA) models to describe explicitly the road tunnel safety level. Journal of Risk Research, 2014, 17(8), 953-959

[37] Kengpol A., Tuammee S.: The development of a decision support framework for a quantitative risk assessment in multimodal green logistics: an empirical study. International Journal of Production Research, 2016, 54(4), 1020-1038

[38] Krystek R. (red.): Zintegrowany System Bezpieczeństwa Transportu, t.2 Uwarunkowania rozwoju integracji systemów transport. WKŁ, Warszawa, 2009

[39] Krystek R., Sitarza M., Żurek J., Gucma S.: Zintegrowany system bezpieczeństwa transport: http://fril.home.pl/zeus/images/stories/Strona/Materialy /02_Zintegrowany_system_bezpieczenstwa_transportu.pdf (25.10.2016)

[40]Linda O., Manic M.: Online Spatio-Temporal Risk Assessment for Intelligent Transportation Systems. IEEE Transactions on Intelligent Transportation Systems, 2011, 12(1), 194-200

[41] López-Atamoros L.G. , Fernández-Villagómez G. , Cruz-Gómez M.J., Duránde-Bazúa C.: Development of a Relative Ranking Risk Index for Risk Assessment in the Transportation of Liquefied Petroleum Gas in Mexico City's Metropolitan Area. Human and Ecological Risk Assessment: An International Journal, 2011, 17(6), 1193-1209

[42]Meng Q., Qu X., Wang X., Yuanita V., CheeWong S.: Quantitative Risk Assessment Modeling for Nonhomogeneous Urban Road Tunnels. Risk Analysis, 2011, 31(3), 382-403

[43] Meng Q., Qu X., Yong K.T., Wong Y.H.: QRA Model-Based Risk Impact Analysis of Traffic Flow in Urban Road Tunnels. Risk Analysis, 2011, 31(12), 1872 -1882 [37]

[44]Nordfjern T., Simsekoglu O., Rundmo T.: A comparison of road traffic culture, risk assessment and speeding predictors between Norway and Turkey. Risk Management, 2012, 14, 202 - 221

[45]Norros I., Kuusela P., Innamaa S., Pilli-Sihvola E., Rajamäki R.: The Palm distribution of traffic conditions and its application to accident risk assessment. Analytic Methods in Accident Research, 2016, 12, 48-65 
[46] Nyvlt O. Privara S., Ferkl L.: Probabilistic risk assessment of highway tunnels. Tunnelling and Underground Space Technology, 2011, 26, 71-82

[47]Pashkevich A., Nowak M.: Road safety risk assessment at pedestrian crossings: a case study from Sułkowice. Scientific Journal of Silesian University of Technology. Series Transport, 2017, 95, 159-170

[48]Prezelj I., Žiberna A.: Consequence-, time- and interdependency-based risk assessment in the field of critical infrastructure. Risk Management, 2013, 15, $100-131$

[49] Pribyl O., Pribyl P, Horak T.: System for deterministic risk assessment in road tunnels. Procedia Engineering, 2017, 192, 336 - 341

[50]Qu X., Meng Q., Yuanita V., Wong Y. H.: Design and implementation of a quantitative risk assessment software tool for Singapore road tunnels. Expert Systems with Applications, 2011, 38, 13827-13834

[51] Ramirez-Florez G., Tabares-Urrea N., Osorio-Gomez J.: Fuzzy AHP for 3PL supplier's performance evaluation considering risk. Revista Facultad de Ingeniería, 2017, 26 (45), 165-172

[52] Salling K.B., Leleur S.: Transport project evaluation: feasibility risk assessment and scenario forecasting. Transport, 2017, 32(2), 180-191

[53] Schubert M., Hoj N.P, Ragnoy A., Buvik H.: Risk Assessment of Road Tunnels using Bayesian Networks. Procedia - Social and Behavioral Sciences, 2012, 48, 2697-2706

[54] Semin V. G., Grigoreva S. V., Dmitrieva T. V., Ilyina E.A.: A Process Model of Risk Management in the System of Management of Strategic Sustainability of Cargo Motor Transport Enterprises. Quality Management, Transport and Information Security, Information Technologies (IT\&MQ\&IS), IEEE Conference on, 2016

[55] Shih H.-Ch., Ma H.-W.: Life cycle risk assessment of bottom ash reuse. Journal of Hazardous Materials, 2011, 190, 308-316

[56] Simões D. , Mosquera G.A.D., Batistela G.C., de Souza Passos J.R., Fenner P.T.: Quantitative Analysis of Uncertainty in Financial Risk Assessment of Road Transportation of Wood in Uruguay. Forests 2016, 7, 130

[57] Tu H., Li H., van Lint H., van Zuylen H.: Modeling travel time reliability of freeways using risk assessment techniques. Transportation Research Part A, 2012, 46, 1528-1540

[58] Wieteska G.: Zarządzanie ryzykiem w łańcuchach dostaw na rynku B2B, Difin, Warszawa 2011

[59] Wilson, M.C.:The impact of transportation disruptions on supply chain performance. Transp. Res. Part E: Logistics Transport Review 2007, 43, 295-320 
Risk assessment in road transport - strategic and business approach Oceny ryzyka w transporcie drogowym-podejście strategiczne i biznesowe

[60] Yaghubpour Z., Esmaeily L., Piran H.R., Behrad A.: Public Transport Risk Assessment through Fault Tree Analysis (FTA). Bulletin de la Société Royale des Sciences de Liège, 2016, 85, 1039 - 1048

[61]Zawiła-Niedźwiecki J.: Zarządzanie ryzykiem operacyjnym w zapewnieniu ciągłości działania organizacji. Edu-Libir, Kraków - Warszawa, 2013

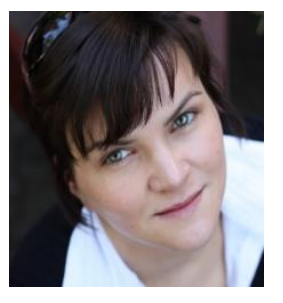

dr Agnieszka Tubis, Politechnika Wroctawska, Wydziat Mechaniczny, Katedra Eksploatacji Systemów Logistycznych, Systemów Transportowych i Układów Hydraulicznych. Rozprawa doktorska dotyczyła wspótpracy producentów i sieci handlowych $w$ obszarze planowania, prognozowania i uzupetniania zapasów wg koncepcji CPFR. Obecne zainteresowania zwiazane sa $z$ koncepcja zarzadzaniem ryzykiem $w$ przedsiębiorstwach transportowych, controllingu procesowego implementowanego w obszarze zarządzania eksploatacja pojazdów oraz systemami doradczymi wspierajacymi procesy decyzyjne kadry menedżerskiej $w$ przedsiębiorstwach transportowych i procesach logistycznych. 